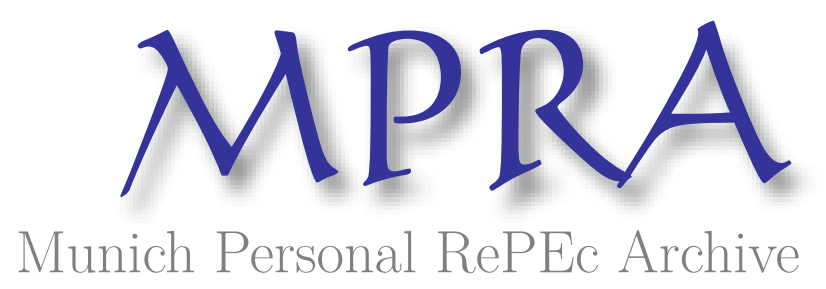

Harmonising Basel III and the Dodd Frank Act through international accounting standards: reasons why international accounting standards should serve as "thermostats"

Ojo, Marianne

University of Heidelberg

24 January 2012

Online at https://mpra.ub.uni-muenchen.de/36149/ MPRA Paper No. 36149, posted 23 Jan 2012 22:51 UTC 


\begin{abstract}
Why should differences between regulatory and accounting policies be mitigated? Because mitigating such differences could facilitate convergence - as well as financial stability.

The paper "Fair Value Accounting and Procyclicality: Mitigating Regulatory and Accounting Policy Differences through Regulatory Structure Reforms and Enforced Self Regulation" illustrates how the implementation of accounting standards and policies, in certain instances, have contrasted with Basel Committee initiatives aimed at mitigating procyclicality and facilitating forward looking provisioning. The paper also highlights how and why differences between regulatory and accounting policies could (and should) be mitigated.

This paper focuses on how recent regulatory reforms - with particular reference to the Dodd Frank Act, impact fair value measurements. Other potential implications for accounting measurements and valuation, will also be considered. Given the tendencies for discrepancies to arise between regulatory and accounting policies, and owing to discrepancies between Basel III and the Dodd Frank Act, would a more imposing and commanding role for international standards not serve as a powerful weapon in harmonizing Basel III and Dodd Frank - whilst mitigating regulatory and accounting policy differences?
\end{abstract}

Key Words: financial stability, OTC derivatives markets, counterparty risks, disclosure, information asymmetry, transparency, living wills, Volcker Rule, Basel III, Basel II, pro cyclicality, international auditing standards, Dodd Frank Act, fair values 


\title{
Harmonising Basel III and the Dodd Frank Act through International Accounting Standards - Reasons why International Accounting Standards Should Serve as "Thermostats"
}

\author{
Marianne Ojo
}

\section{A. Introduction}

Whilst several conflicts persist between Basel III and the Dodd Frank Act, amongst which include the fact that:

- the Dodd Frank Act not only prohibits US regulators from relying on external credit ratings in any regulation - thus ,making the implementation of Basel reforms relating to securitization and resecuritizations impossible, ${ }^{2}$

- it places US banks at a possible ,,competitive disadvantage under Basel III," 3 as well as; imposes additional cost burdens and problematic implementation issues (in matters relating to consistency, comparability and reliability of risk weighting measurements) for foreign financial firms;

Basel III and the Dodd Frank Act share many commonalities.

\section{Basel III and the Dodd Frank Act are both macro prudential regulatory measures aimed at improving financial stability.}

Recent measures aimed at fostering financial stability have focussed on macro prudential measures as well as measures aimed at mitigating pro cyclicality. The Basel Committee on Banking Supervision has been engaged in several initiatives, in collaboration with its introduction of Basel III, which are aimed at mitigating procyclicality. Such initiatives include: ${ }^{4}$

- the assessment and dampening of the cyclicality of minimum capital requirements;

- the facilitation of forward-looking provisioning;

\footnotetext{
1 Visiting Scholar, University of Heidelberg; Legal Scholarship Network Email:marianneojo@ @otmail.com. This paper, as with all previous and subsequent papers, is dedicated to the loving and enduring memory of my beloved mum, Mrs Florence Ojo (University of Heidelberg, Schiller College 1978 -1980).

2 See H Scott, „Reducing Systemic Risk Through the Reform of Capital Regulation“ Journal of International Economic Law 13(3) at pages 766-767.

${ }^{3}$ See Speech by Stefan Walter, Secretary General of the Basel Committee on Banking Supervision at the Risk Europe Pre Conference Summit, Brussels 4 April 2011.

${ }^{4}$ R Moreno, „Policymaking from a Macro prudential Perspective“ BIS Working Paper No 336, January 2011 at page 13 of 24
} 
- the adoption of a regulatory framework for capital conservation and countercyclical buffers;

- the introduction of a minimum leverage ratio.

Disclosure and transparency constitute fundamental elements which foster accountability. Transparency is considered to be ,a beneficial element in agency relationships because more information about the agent makes the agent more accountable to the principal." ${ }^{, 5}$ However circumstances whereby ,committing to the concealment of certain kind of information" could prove beneficial to the principal, have also been identified. ${ }^{6}$

The Dodd Frank $\mathrm{Act}^{7}$ is an Act whose aims include the promotion of the financial stability of the United States through improving accountability and transparency in the financial system, the ending of the concept of "too big to fail", the protection of American taxpayers though the ending of bailouts, and the protection of consumers from abusive financial services practices. ${ }^{8}$

Title One of the Act, also known as the "Financial Stability Act of 2010"9 (and particularly subtitle A under this Title), is dedicated exclusively towards consideration of measures which have been (and are being) instigated to promote financial stability. Under subtitle A, the establishment of a "Financial Stability Oversight Council" is highlighted whose purposes include: ${ }^{10}$

- the identification of risks to the financial stability of the United States that could arise from the material financial distress or failure, or ongoing activities, of large, interconnected bank holding companies or non bank financial companies, or that could arise outside the financial services marketplace;

- the promotion of market discipline, by eliminating expectations on the part of shareholders, creditors, and counterparties of such companies that the Government will shield them from losses in the event of failure; and

- responding to emerging threats to the stability of the United States financial system.

\footnotetext{
${ }^{5}$ A Prat, „The Wrong Kind of Transparency“ LSE STICERD Research Paper No. TE439 October 2002 at page 5 of $51<$ http://papers.ssrn.com/sol3/papers.cfm?abstract_id=1160984>

6 ibid at page 46 of 51

7 "Dodd-Frank Wall Street Reform and Consumer Protection Act'. See http://www.sec.gov/about/laws/wallstreetreform-cpa.pdf at page 1

${ }^{8}$ ibid

${ }^{9}$ See section 101 of the Act

${ }^{10}$ See section 112; For duties of the Council, also refer to subsection a (2) of section 112. Amongst its duties, a significant one being "the annual reporting of financial market and regulatory developments, including insurance and accounting regulations and standards, along with an assessment of those developments on the stability of the financial system."
} 


\section{B. To What Extent do Basel III and the Dodd Frank Act Respectively Facilitate Greater Transparency and Disclosure?}

Financial stability functions and objectives, it is argued, ${ }^{11}$ are often considered to be less defined and more ambiguous than monetary policy objectives. Hence financial stability functions and objectives could be considered to be in greater need of more defined, clearer, and more explicit mandates. Reasons attributed to the need for explicit mandates with explicit objectives in order to facilitate effective execution of the financial stability function are as follows: ${ }^{12}$

- It helps those in the private sector that are subject to policy to be able to predict the likely direction of official actions under different scenarios

- Policy actions to constrain risk taking activities which threaten financial stability

However, even though advantages exist in stipulating clear mandates, certain disadvantages also emanate from the stipulation of mandates in a "clear and explicit" way which does not provide for flexibility in relation to an area such as financial stability - an area which, to a large extent, involves contingency issues ${ }^{13}$ and uncertainty.

In his paper, "Why Basel II Failed and Why Any Basel III is doomed", ${ }_{14}$ Ranjit Lall highlights various deficiencies attributed to Basle II. He highlights the Basel Committee's

\footnotetext{
11 "Maintain financial stability is less easily interpreted than maintain price stability since price stability can be numerically approximated in terms of a generally agreed index - whereas financial stability cannot. Furthermore, financial stability objectives are often expressed in directional, rather than absolute terms: for example, "to promote" or "to support" or "to endeavour to achieve". No metric exists to understand how much promoting, supporting or endeavouring is intended." See Bank for International Settlements, "Central Bank Governance and Financial Stability" A Report by a Study Group May 2011 <http:www.bis.org/publ/othp14.pdf> at page 28

${ }^{12}$ See ibid at page 29

13 "Given the current state of knowledge about what constitutes financial stability, and its main drivers, attempting to direct policy actions by way of explicit objectives, may create practical difficulties. Three reasons being: be favorable

It would be unfortunate if explicit objectives excluded policy options which turn out to

A clear objective statement directing the policy to ensure financial stability, without indicating the limits to which the authorities are prepared to insure private agents against tail risk events, may induce greater risk taking than available policy instruments are able to cope with.

The unpredictability of financial crises
}

For these reasons, it is important to have flexible legislation which is adaptable to potential changes" see ibid at page 30

${ }^{14}$ Basel II's failure, in Lall's opinion can be summed up as a result of "regulatory capture". "A small group of international banks were able to take control of the Basel process, transforming the rules of international 
failure to achieve its first and second aims for the Accord - the result of its decision to allow wealthy banks to use internal ratings. He also refers to the Basel Accord's third aim, and the related developments in the treatment of market risk, the trading book, and securitization that caused Basel II to fall short of providing a more 'comprehensive' approach to risk management. The "very real social cost" of Basel II's failure, illustrating the devastating consequences of captured capital regulation, as well as his opinion that the Basel Committee has one of the worst records of all international standard-setters in terms of transparency, representation, and accountability, are also reiterated.

Whilst the devastating impact of Basel II on pro cyclicality is a renowned flaw which is attributed to Basel II, some measures aimed at improving greater disclosure, transparency and accountability, particularly within Over-the-Counter derivatives markets, through standardization, are evidenced by recent efforts of the Financial Stability Board. ${ }^{15}$

Title VII of the Dodd Frank Act, titled "The Wall Street Transparency and Accountability Act of 2010" "sets out a new framework for regulatory and supervisory oversight of the Over-the-Counter (OTC) derivatives market." Within this Title, "many swaps that are currently executed in the OTC market will be required to be cleared through derivatives clearing organizations." 16

SEC. 712. REVIEW OF REGULATORY AUTHORITY, subsections (a)(1) and (a) (2) provide as follows:

(a) CONSULTATION.-

(1) COMMODITY FUTURES TRADING COMMISSION.-Before commencing any rulemaking or issuing an order regarding swaps, swap dealers, major swap participants, swap data repositories, derivative clearing organizations with regard to swaps, persons associated with a swap dealer or major swap participant, eligible contract participants, or swap execution facilities pursuant to this subtitle, the Commodity Futures Trading Commission shall consult and coordinate to the extent possible with the Securities and Exchange Commission and the prudential regulators for the purposes of assuring regulatory consistency and comparability, to the extent possible.

(2) SECURITIES AND EXCHANGE COMMISSION.-Before commencing any rulemaking or issuing an order regarding security based swaps, security-based swap dealers, major security-based swap participants, security-based swap data repositories, clearing agencies with regard to security-based swaps, persons

capital regulation to maximize their profits at the expense of those without a seat at the decision-making table."

R Lall, "Why Basel II Failed and Why Any Basel III is doomed" Global Economic Governance

Programme GEG Working Paper 2009/52 October 2009 at page $12<$

http://www.globaleconomicgovernance.org/wp-content/uploads/GEG-Working-paper-Ranjit-Lall.pdf>

${ }^{15}$ See Financial Stability Board, "Implementing OTC Derivatives Market Reforms" Oct 2010

http://www.financialstabilityboard.org/publications/r_101025.pdf

16 "For example, exchanges or clearing houses, unless the organizations do not accept the swaps for clearing. Swaps not cleared through a clearing organization would be reported to the Commodities Futures Trading Commission (CFTC), the SEC, or a swap data repository. The Act imposes capital requirements on swap entities, which are swap dealers and major swap participants, as well as initial and variation margin requirements for uncleared swaps. Additionally, real time public data reporting of swap transactions is required under Title VII $>$ " See KPMG, "The Dodd Frank: Could There Be Accounting Consequences?" at page 5 of $8 \mathrm{http}: / /$ www.kpmg.com/US/en/IssuesAndInsights/ArticlesPublications/Documents/dodd-frankaccounting-consequences.pdf 
associated with a security-based swap dealer or major security based swap participant, eligible contract participants with regard to security-based swaps, or security-based swap execution facilities pursuant to subtitle B, the Securities and Exchange Commission shall consult and coordinate to the extent possible with the Commodity Futures Trading Commission and the prudential regulators for the purposes of assuring regulatory consistency and comparability, to the extent possible.

Title VII's provisions are considered to signify a marked "departure from current practice - though certain exemptions will be available, including an "end user exemption" from clearing for a swap counterparty that is not a financial entity - that is, using the $\operatorname{swap}^{17}$ to hedge or mitigate commercial risk." 18

In relation to disclosure, ${ }^{19}$ Title IX, section 956 of the Dodd Frank Act ENHANCED COMPENSATION STRUCTURE REPORTING also provides as follows:

\title{
(a) ENHANCED DISCLOSURE AND REPORTING OF COMPENSATION ARRANGEMENTS.-
}

(1) IN GENERAL.-Not later than 9 months after the date of enactment of this title, the appropriate Federal regulators jointly shall prescribe regulations or guidelines to require each covered financial institution to disclose to the appropriate Federal regulator the structures of all incentive-based compensation arrangements offered by such covered financial institutions sufficient to determine whether the compensation structure-

(A) provides an executive officer, employee, director, or principal shareholder of the covered financial institution with excessive compensation, fees, or benefits; or

(B) could lead to material financial loss to the covered financial institution.

\section{To What Extent does the Dodd Frank Act Impact Fair Value Measurements?}

A previous paper ${ }^{20}$ has highlighted how accounting standards and Basel II contribute to

\footnotetext{
17 "Swap as defined in the Dodd Frank Act is considered to be very broad - encompassing derivatives other than swaps (such as options or many forward contracts) as well as many other types of agreements, contracts and transactions not previously considered derivatives." See ibid

${ }^{18}$ see ibid.

${ }^{19}$ Also see SEC. 725. relating to DERIVATIVES CLEARING ORGANIZATIONS.
}

\author{
“(L) PUBLIC INFORMATION.- \\ “(i) IN GENERAL.-Each derivatives clearing organization shall provide to market participants sufficient \\ information to enable the market participants to identify and evaluate accurately the risks and costs \\ associated with using the services of the derivatives clearing organization. \\ “(ii) AVAILABILITY OF INFORMATION.-Each derivatives clearing organization shall make \\ information concerning the rules and operating and default procedures governing the clearing and \\ settlement systems of the derivatives clearing organization available to market participants." \\ “(iii) PUBLIC DISCLOSURE. - relating to what information each derivatives clearing organization shall \\ disclose publicly and to the Commission. \\ ${ }^{20}$ M Ojo, „The Role of the IASB and Auditing Standards in the Aftermath of the 2008/2009 \\ Financial Crisis“"European Law Journal, Vol. 16, No. 5, September 2010, pp. 604-623 at page 612; Also
}


procyclicality. Further, the pro cyclical nature of accounting, is attributed to two principal elements:

Fair value measurements

The treatment of impairments.

Whilst results of a certain sample generated by $\mathrm{Khan}^{21}$ illustrate and support the evidence that ,a more fair value-oriented accounting regime is associated with an increase in bank contagion above and beyond that which exists as a result of trade and financial linkages in the banking industry", Laux and Leuz argue in contrast (and based on their analysis), that fair value accounting (frequently also referred to as markto-market accounting), is unlikely to have contributed to the severity of the 2008 Financial Crisis in a major way. ${ }^{22}$ Furthermore, they add that ,while there may have been downward spirals or asset fire sales in certain markets, little evidence supports the fact that such effects are the result of fair value accounting."

\section{Advantages and Disadvantages of Fair Value Measurements}

The principal advantage attributed to fair value measurements is namely, the value of information they incorporate in the financial statements - such value being more complete and accurate than that provided by historical cost accounting.

Problems identified with fair value accounting, as highlighted by Ball, include: ${ }^{23}$

- Market liquidity is a potentially important issue in practice and spreads could be large enough to cause substantial uncertainty about fair values. In illiquid markets, trading by managers could influence traded - as well as quoted prices hence allowing them to manipulate fair value estimates.

- The potential for fair value accounting to become „mark to model“ accounting when liquid market prices are not available

- Tendency for fair value accounting to increase opportunities for manipulation when ,mark to model“" accounting is employed to simulate market prices (since

see M Grande, Accounting and Procyclicality, Conference on Financial Reporting in a Changing World at page 2

${ }^{21}$ U Khan, „Does Fair Value Accounting Contribute to Systemic Risks in the Banking Industry?“ at page 4 <http://papers.ssrn.com/sol3/papers.cfm?abstract_id=1327596>

${ }^{22}$ See C Laux and C Leuz, „Did Fair Value Accounting Contribute to the Financial Crisis?“ ECGI Working Paper Series in Finance, Working Paper No 266 October 2009 at page 3.

<http://papers.ssrn.com/sol3/papers.cfm? abstract_id=1487905>

${ }^{23}$ R Ball, „International Financial Reporting Standards (IFRS): Pros and Cons for Investors“ at pages 21 and $22<\mathrm{http}: / /$ papers.ssrn.com/sol3/papers.cfm?abstract_id=929561〉 
managers are able to influence both the choice of models and the parameter estimates).

According to KPMG, one likely accounting related consequence of the requirements to clear swaps is attributed to measurements and disclosures of fair value under ASC Topic 820, Fair Value Measurements and Disclosures. "Fair value measurements", it is contended, "take into account counterparty credit risk and collateral. To the extent clearing organizations become central counterparties to swap transactions (instead of the original counterparty) and/or collateral maintenance is required, fair value measurements of swaps will be different from what they would have been absent those characteristics." The use of clearing organizations as central counterparties, in their opinion, may also "impact a company's eligibility to offset swaps in its balance sheet." 24

\section{Conclusion}

Whilst recent initiatives promulgated by the Basel Committee, through the Basel III framework (initiatives aimed at mitigating pro cyclical effects), have been elaborated on under the introductory section of this paper, the implications of the Dodd Frank Act for fair value accounting continue to unravel. Further potential accounting implications attributed to the Dodd Frank Act, which have been identified by KPMG in their report, include: ${ }^{25}$

- That attributed to Title IX requirements (titled Investor Protections and Improvements to the Regulation of Securities) under which section 941 requires any securitizer to retain an economic interest in a portion of the credit risk for any asset the securitizer transfers, sells or conveys to a third party through the issuance of asset backed securities. ${ }^{26}$

- That attributed to Title VII requirements ${ }^{27}$ whereby the "potential novation of existing derivatives may arise - either through a banking entity pushing out the swap or through submission of the swap to a clearing organization.,"28

\footnotetext{
${ }^{24}$ See KPMG, "The Dodd Frank: Could There Be Accounting Consequences?" at page 5 of 8 http://www.kpmg.com/US/en/IssuesAndInsights/ArticlesPublications/Documents/dodd-frank-accountingconsequences.pdf

${ }^{25}$ See ibid at pages 1-2

26 "Companies that normally sell loans and receivables through securitizations, including potential recourse factoring, will need to determine whether the risk retention provisions will apply to their current programs, including applicability of exemptions. If those provisions apply, then a company would be required to retain credit risk, raising the question of whether the financial assets transferred to the securitization should be derecognized. For financial institutions, if more assets are retained in a company's balance sheet, required capital levels will increase, thereby potentially decreasing the desirability of accessing securitization markets. The consolidation and de recognition requirements are complex and all forms of involvements through required risk retention would need to be assessed." See ibid at page 2

${ }^{27}$ The Wall Street Transparency and Accountability Act of 2010

${ }^{28}$ It is added that "an assessment would need to be made as to whether the exchange of one counterparty to the swap for a different counterparty would result in swap being accounted for as the continuation of the existing swap or as an extinguishment of the existing swap combined with issuance of a new swap."
} 


\section{- That attributed to the Volcker Rule ${ }^{29}$ and Living Wills provisions ${ }^{30}$}

"Future efforts to revise capital adequacy standards must both observe basic standards of due process and ensure that information asymmetries are as small as possible principally, but not exclusively, by maintaining some kind of distance between supervisory bodies and the banking industry. Though difficult in practice to achieve, if implemented faithfully, these changes would go a long way towards ensuring that the next time regulators set out to revise international capital standards, they achieve every one of their aims." 31

Further concerns attributed to the new Basel III framework relate to its "facilitation of the shadow banking system whilst constraining the bank sector." 32 The new, more stringent capital and liquidity requirements introduced through Basel III are likely to impact the more highly regulated banking sector since it is likely that there will be greater incentives to transact in less stringent regulated sectors such as the shadow banking system or through less stringent regulated capital instruments. ${ }^{33}$

29 "The statutory provisions that make up the Volcker Rule generally prohibit banking entities from engaging in two types of activities: 1) proprietary trading and 2) acquiring an ownership interest in, sponsoring, or having certain relationships with a hedge fund or private equity fund (each a covered fund). These statutory provisions apply, in general, to insured depository institutions; companies that control an insured depository institution; and foreign banks with a branch, agency, or subsidiary bank in the United States, as well as to an affiliate of one of these entities.

The statutory definition of a fund covered under the Volcker Rule is quite broad. The statute also quite broadly prohibits any banking entity that serves as the investment manager, adviser, or sponsor to a covered fund, or that organizes and offers a covered fund, from engaging in certain transactions with the fund, including lending to, or purchasing assets from, the fund.

One of the more difficult tasks in implementing the statutory prohibitions is distinguishing between prohibited proprietary trading activities and permissible market-making activities. This distinction is important because of the key role that market makers play in facilitating liquid markets in securities, derivatives, and other assets. The distinction between prohibited proprietary trading and permissible market making can be difficult to draw, because these activities share several important characteristics." See D Tarullo, "The Volcker Rule" Testimony before the Subcommittee on Capital Markets and Government Sponsored Enterprises and the Subcommittee on Financial Institutions and Consumer Credit, Committee on Financial Services, U.S. House of Representatives, Washington, D.C. January 18, 2012 http://www.federalreserve.gov/newsevents/testimony/tarullo20120118a.htm

${ }^{30}$ Whereby it is asserted that "both the Volcker Rule and Living Will Provisions could lead to institutions selling parts of their businesses in order to comply with regulations. "

${ }^{31}$ See R Lall, "Why Basel II Failed and Why Any Basel III is doomed" Global Economic Governance Programme GEG Working Paper 2009/52 October 2009 at page $25<$ http://www.globaleconomicgovernance.org/wp-content/uploads/GEG-Working-paper-Ranjit-Lall.pdf>

${ }^{32}$ See BRIEF, ,Deutsche Bank CFO Says Concerned New Basel Rules Allow Shadow Banking System Whilst Constraining Bank Sector" $<$ http://www.finanznachrichten.de/nachrichten-2011-05/20264700briefdeutsche- bank-cfo-says-concerned-new-basel-rules-allow-shadow-banking-system-020.htm

${ }^{33}$ See M Ojo, "Financial Stability, New Macro Prudential Arrangements and Shadow Banking: Regulatory Arbitrage and Stringent Basel III Regulations" http://mpra.ub.unimuenchen.de/31319/1/MPRA_paper 31319.pdf and http://papers.ssrn.com/sol3/papers.cfm?abstract_id $=1859543$ 
Given a consideration of the impacts of the Basel frameworks and that of the Dodd Frank Act on pro cyclicality and fair value measurements, even though initiatives are being undertaken to mitigate pro cyclical effects (as well as facilitate financial stability through increased transparency and disclosure), it has to be said that a more prominent role for international accounting standards would serve as a formidable means in mitigating discrepancies between accounting and regulatory policies, whilst ensuring that some kind of distance exists between supervisory bodies and the banking industry - such that an incidence of regulatory capture is avoided. 


\section{REFERENCES}

Ball R, „International Financial Reporting Standards (IFRS): Pros and Cons for Investors" <http://papers.ssrn.com/sol3/papers.cfm?abstract_id=929561>

Bank for International Settlements, "Central Bank Governance and Financial Stability" A Report by a Study Group May 2011 <http:www.bis.org/publ/othp14.pdf>

BRIEF, „Deutsche Bank CFO Says Concerned New Basel Rules Allow Shadow Banking System Whilst Constraining Bank Sector" $<$

http://www.finanznachrichten.de/nachrichten-2011-05/20264700-briefdeutsche- bankcfo-says-concerned-new-basel-rules-allow-shadow-banking-system-020.htm

Dodd-Frank Wall Street Reform and Consumer Protection Act http://www.sec.gov/about/laws/wallstreetreform-cpa.pdf

Financial Stability Board, "Implementing OTC Derivatives Market Reforms" Oct 2010 http://www.financialstabilityboard.org/publications/r_101025.pdf

Grande M, Accounting and Procyclicality, Conference on Financial Reporting in a Changing World

Khan U, „Does Fair Value Accounting Contribute to Systemic Risks in the Banking Industry?" http://papers.ssrn.com/sol3/papers.cfm?abstract_id=1327596

KPMG, "The Dodd Frank: Could There Be Accounting Consequences?" http://www.kpmg.com/US/en/IssuesAndInsights/ArticlesPublications/Documents/doddfrank-accounting-consequences.pdf

Lall R, "Why Basel II Failed and Why Any Basel III is doomed" Global Economic Governance Programme GEG Working Paper 2009/52 October 2009 < http://www.globaleconomicgovernance.org/wp-content/uploads/GEG-Working-paperRanjit-Lall.pdf> 
Laux C and Leuz C, „Did Fair Value Accounting Contribute to the Financial Crisis?“ ECGI Working Paper Series in Finance, Working Paper No 266 October 2009

<http://papers.ssrn.com/sol3/papers.cfm? abstract_id=1487905>

Moreno R, „Policymaking from a Macro prudential Perspective“ BIS Working Paper No 336, January 2011

Ojo M, "Financial Stability, New Macro Prudential Arrangements and Shadow Banking: Regulatory Arbitrage and Stringent Basel III Regulations" http://mpra.ub.unimuenchen.de/31319/1/MPRA_paper_31319.pdf and http://papers.ssrn.com/sol3/papers.cfm?abstract_id=1859543

Ojo M, „The Role of the IASB and Auditing Standards in the Aftermath of the 2008/2009 Financial Crisis“ European Law Journal, Vol. 16, No. 5, September 2010, pp. 604-623

Prat A, „The Wrong Kind of Transparency“ LSE STICERD Research Paper No. TE439 October 2002 at page 5 of 51

<http://papers.ssrn.com/sol3/papers.cfm?abstract_id=1160984>

Scott H, „Reducing Systemic Risk Through the Reform of Capital Regulation“ Journal of International Economic Law 13(3) at pages 766-767.

Tarullo D, "The Volcker Rule" Testimony before the Subcommittee on Capital Markets and Government Sponsored Enterprises and the Subcommittee on Financial Institutions and Consumer Credit, Committee on Financial Services, U.S. House of Representatives, Washington, D.C. January 18, 2012

http://www.federalreserve.gov/newsevents/testimony/tarullo20120118a.htm

Walter S, Secretary General of the Basel Committee on Banking Supervision at the Risk Europe Pre Conference Summit, Brussels 4 April 2011. 